\title{
First Record of Age 0+ Atlantic Whitefish, Coregonus huntsmani, from the Wild
}

\author{
Dan J. Hasselman ${ }^{1,3}$, Phillip LONGUE ${ }^{2}$, and Rod G. BRADFORD ${ }^{2}$ \\ ${ }^{1}$ Biology Department, Acadia University, Wolfville, Nova Scotia B4P 2R6 Canada \\ ${ }^{2}$ Department of Fisheries and Oceans; Bedford Institute of Oceanography, P. O. Box 1006, 1 Challenger Drive, Dartmouth, \\ Nova Scotia B2Y 4A2 Canada \\ ${ }^{3}$ Corresponding author (Biology Department, Dalhousie University, Halifax, Nova Scotia B3H 4J1 Canada
}

Hasselman, Dan J., Phillip Longue, and Rod G. Bradford. 2005. First record of age 0+ Atlantic Whitefish, Coregonus huntsmani, from the wild. Canadian Field-Naturalist 119(2): 294-295.

A small school of juvenile Atlantic Whitefish ( 20-30 individuals) were observed in the littoral zone of Hebb Lake (Petite Rivière watershed), Nova Scotia in June 2000. Of these, a single individual was captured with a beach seine, and confirmed to be a young-of-the-year specimen. This is the first documented report of the occurrence of wild Atlantic Whitefish juveniles. Occupation of the littoral zone into early summer by young-of-the-year Atlantic Whitefish may have implications for predation by invasive Smallmouth Bass.

Key Words: Atlantic Whitefish, Coregonus huntsmani, wild juvenile, first record, Hebb Lake, Petite Rivière watershed, Nova Scotia.

On 26 June 2000, during daylight experimental angling on Hebb Lake (Petite Rivière watershed, Nova Scotia; N44 $\left.^{\circ} 21^{\prime} 00 ; \mathrm{W}^{\circ} 4^{\circ} 34^{\prime} 00\right)$ to assess susceptibility of Atlantic Whitefish (Coregonus huntsmani Scott, 1987) to incidental capture, a school of small fish were observed in pursuit of an $\sim 8 \mathrm{~cm}$ in length floating imitation minnow during its retrieval to the shore from a cast destination of approximately $\sim 3 \mathrm{~m}$ depth. Although none of these fish were hooked, they remained near the shore for a sufficient period of time to determine that they were of similar size, silvery in colouration, and in possession of an adipose fin. A single Atlantic Whitefish ( $8.4 \mathrm{~cm}$ total length; $4.8 \mathrm{~g}$ total weight) was captured after re-casting the lure, and drawing a smallmeshed beach seine behind and across the line of retrieval to bar escape. The specimen was aged (scale method), determined to be a young-of-the-year (y-o-y) specimen, and is archived at the Nova Scotia Museum of Natural History (Catalogue Number: NSM 85368).

These are the first observations of juvenile Atlantic Whitefish in the wild, as none were available to support previous taxonomic descriptions (Smith and Todd 1992; Edge et al. 1991; Piers 1927; Huntsman 1922) or ecological assessments (Edge and Gilhen 2001; Edge 1984, 1987). Recent (May-August, 2000) systematic temporal and spatial sampling with baited minnow pots, fyke nets, and beach-seines failed to collect a single specimen, although fish species known to frequent the shallow $(\leq 1 \mathrm{~m})$ littoral zone of most Nova Scotia lakes (i.e., American Eel (Anguilla rostrata), Banded Killifish (Fundulus diaphanus), Brown Bullhead (Ameiurus nebulosus), Creek Chub (Semotilus atromaculatus), Golden Shiner (Notemigonus crysoleucas), White Sucker (Catostomus commersoni), White Perch (Morone americana), and Yellow Perch (Perca flavescens)) were captured (R. G. Bradford, unpublished data). Similar findings were previously confirmed by Edge (1987).
Irrespective of the rarity of known occurrences of juvenile Atlantic Whitefish within inshore areas of shallow-moderate depth, there are indications that the species is not precluded from occupation of zones of warmer water temperatures. Young-of-the-year Atlantic Whitefish reared in captivity routinely tolerate summer temperatures of up to $24^{\circ} \mathrm{C}$ (John Whitelaw, Department of Fisheries and Oceans, Mersey Biodiversity Centre, Milton, Nova Scotia, personal communication). Recorded June water temperatures at $1 \mathrm{~m}$ depth in Hebb Lake are a comparable $19.9^{\circ} \pm 3.2^{\circ} \mathrm{C}$ (mean \pm s.d.), and range from $14.2^{\circ}$ to $26.1^{\circ} \mathrm{C}$ (R. G. Bradford, unpublished data). Young coregonids generally tolerate higher temperatures than do their adult counterparts (Fry 1937). Therefore, the presence of y-o-y Atlantic Whitefish in lacustrine habitat shallower than the depth of the summer hypolimnion cannot be discounted.

These observations have significance as an indication that small-bodied Atlantic Whitefish may be susceptible to direct predation by Smallmouth Bass (Micropterus dolomieu), a non-native invasive species illegally introduced into the upper Petite Rivière drainage during the late 1990s (J. Gilhen, Nova Scotia Museum of Natural History, personal communication; Atlantic Whitefish Conservation and Recovery Team 2004). Smallmouth Bass now reproduce successfully in Minamkeak Lake, the upper most of three lakes that, when combined, total no more than $16 \mathrm{~km}^{2}$ of aquatic habitat, and represents the global distribution of Atlantic Whitefish (Bradford et al. in preparation). Colonization of the other two lakes by smallmouth bass is probable in light of the experience with this aquatic invasive species elsewhere in North America (Vander Zanden et al. 1999, 2004). Occurrence of y-o-y Atlantic Whitefish in the limnetic zone during the seasons of active foraging by Smallmouth Bass may therefore be a matter of importance to the survival of the species, but further study is required to determine the validity of this supposition. 


\section{Acknowledgments}

Observations occurred during field activities in support of the Atlantic Whitefish recovery strategy. Funding was provided by the Canadian Department of Fisheries and Oceans.

\section{Documents Cited}

Bradford, R. G., D. Longard, and P. Longue. In prepration Status, trend, and recovery considerations in support of an allowable harm assessment for Atlantic whitefish (Coregonus huntsmani), Canadian Stock Assessment Secretariat Research Document 2004, Department of Fisheries and Oceans, Dartmouth, Nova Scotia.

\section{Literature Cited}

Atlantic Whitefish Conservation and Recovery Team. 2004. National recovery strategy for the Atlantic Whitefish (Coregonus huntsmani). Department of Fisheries and Oceans. 2004. Halifax, pages 34.

Fry, F. E. J. 1937. The summer migration of the cisco, Leucichthys artedii (Le Sueur), in Lake Nipissing, Ontario. Publications of the Ontario Fisheries Research Laboratory 55: 9-91.

Edge, T. A. 1984. Preliminary status of the Acadian whitefish, Coregonus canadensis, in southern Nova Scotia. Canadian Field-Naturalist 98: 86-90.

Edge, T. A. 1987. The systematics, distribution, ecology and zoogeography of the endangered Acadian whitefish, Coregonus canadensis Scott, 1967, in Nova Scotia, Canada. M.Sc. University of Ottawa.
Edge, T. A., D. E. McAllister, and S. U. Qadri. 1991. Meristic and morphometric variation between the endangered Acadian whitefish, Coregonus huntsmani, and the lake whitefish, Coregonus clupeaformis, in the Canadian Maritime Provinces and the state of Maine, USA. Canadian Journal of Fisheries and Aquatic Sciences 48: 2140-2151.

Edge, T. A., J. Gilhen. 2001. Updated status report on the endangered Atlantic Whitefish, Coregonus huntsmani. Canadian Field-Naturalist 115: 635-651.

Huntsman, A. J. 1922. The fishes of the Bay of Fundy. Contribution to Canadian Biology 3: 49-72.

Piers, H. 1927. Coregonus labridoricus, the Sault Whitefish, an interesting addition to the freshwater fish fauna of Nova Scotia. Transactions of the Nova Scotia Institute of Science 16: 92-95.

Smith, G. R., and T. N. Todd. 1992. Morphological cladistic study of coregonine fishes. Polish Archives of Hydrobiology 39: 479-490.

Vander Zanden, M. J., J. M., Casselman, and J. B. Rasmussen. 1999. Stable isotope evidence for the food web consequences of species invasions in lakes. Nature 401: 464-467.

Vander Zanden, M. J., J. D. Olden, J. H. Thorne, and N. E. Mandrak. 2004. Predicting occurrences and impacts of smallmouth bass introductions in north temperate lakes. Ecological Applications 14: 132-148.

Received 2 November 2004

Accepted 12 March 2005 